\title{
Deformation Behavior and Properties of 7075 Aluminum Alloy under Electromagnetic Hot Forming
}

\author{
Zhihao Du ${ }^{1}\left(\mathbb{D}\right.$, Zanshi Deng $^{1}$, Xiaohui Cui ${ }^{1,2,3, * \mathbb{D}}$ and Ang Xiao ${ }^{1}$ \\ 1 College of Mechanical and Electrical Engineering, Central South University, Changsha 410083, China; \\ dzh7695782@126.com (Z.D.); dzscsu@csu.edu.cn (Z.D.); xiaoang@csu.edu.cn (A.X.) \\ 2 Light Alloy Research Institute, Central South University, Changsha 410083, China \\ 3 State Key Laboratory of High Performance Complex Manufacturing, Central South University, \\ Changsha 410083, China \\ * Correspondence: cuixh622@csu.edu.cn; Tel.: +86-153-8802-8791
}

Citation: Du, Z.; Deng, Z.; Cui, X.; Xiao, A. Deformation Behavior and Properties of 7075 Aluminum Alloy under Electromagnetic Hot Forming. Materials 2021, 14, 4954. https:// doi.org/10.3390/ma14174954

Academic Editor: Frank Czerwinski

Received: 19 July 2021

Accepted: 24 August 2021

Published: 30 August 2021

Publisher's Note: MDPI stays neutral with regard to jurisdictional claims in published maps and institutional affiliations.

Copyright: (C) 2021 by the authors. Licensee MDPI, Basel, Switzerland. This article is an open access article distributed under the terms and conditions of the Creative Commons Attribution (CC BY) license (https:// creativecommons.org/licenses/by/ $4.0 /)$.

\begin{abstract}
High-strength 7075 aluminum alloy is widely used in the aerospace industry. The forming performance of 7075 aluminum alloy is poor at room temperature. Therefore, hot forming is mainly adopted. Electromagnetic forming is a high-speed forming technology that can significantly improve the forming limit of difficult-to-deform materials. However, there are few studies on electromagnetic hot forming of 7075-T6 aluminum alloy. In this study, the deformation behavior of 7075-T6 aluminum alloy in the temperature range of $25^{\circ} \mathrm{C}$ to $400{ }^{\circ} \mathrm{C}$ was investigated. As the temperature increased, the sheet forming height first decreased, then increased. When the forming temperature is between $200{ }^{\circ} \mathrm{C}$ and $300{ }^{\circ} \mathrm{C}, \eta$ phase coarsening leads to a decrease in stress and hardness of the material. When the forming temperature is between $300^{\circ} \mathrm{C}$ and $400{ }^{\circ} \mathrm{C}$, continuous dynamic recrystallization of 7075 aluminum alloy occurs, resulting in grain refinement and an increase in stress and hardness. The results of numerical simulations and experiments all show that the forming height and deformation uniformity of the sheet metal are optimal at $400{ }^{\circ} \mathrm{C}$, compared to $200{ }^{\circ} \mathrm{C}$.
\end{abstract}

Keywords: 7075-T6 aluminum alloy; electromagnetic forming; hot forming; numerical simulation; mechanical property

\section{Introduction}

With rapid developments in aerospace engineering, high-speed trains, and large aircraft, the demand for high-strength, lightweight structural parts is increasing. Highstrength and lightweight alloy structural parts can improve material properties. Highstrength aluminum alloys offer the advantages of low density and high strength [1,2] and are widely used in the aerospace industry. However, poor plasticity of high-strength aluminum alloys at room temperature limits their application $[3,4]$.

Under hot forming conditions, the yield stress of high-strength aluminum alloys decreases dramatically, and the plastic deformation ability increases. Xiao et al. [5] studied the hot compression test of an Al- $\mathrm{Zn}-\mathrm{Mg}-\mathrm{Cu}$ alloy in the deformation temperature range of $350-450{ }^{\circ} \mathrm{C}$ and the strain rate range of $0.001-1 \mathrm{~s}^{-1}$. Based on the microstructure characteristics, the optimum processing parameters were obtained in the temperature range of $380-405{ }^{\circ} \mathrm{C}$ and the strain rate range of $0.006-0.035 \mathrm{~s}^{-1}$. Wang et al. [6] studied the formability of AA2024 aluminum alloy at temperatures ranging from $350{ }^{\circ} \mathrm{C}$ to $493{ }^{\circ} \mathrm{C}$ using tensile tests. The highest plastic forming performance was observed at $450{ }^{\circ} \mathrm{C}$. However, the ductility of the material sharply declined when the temperature exceeded $450{ }^{\circ} \mathrm{C}$. This is due to precipitation of solute atoms on grain boundaries, resulting in grain boundary separation, which reduces the ductility of the material. Kumar et al. [7] studied the tensile properties of 7020-T6 aluminum alloy in a temperature range of $150{ }^{\circ} \mathrm{C}$ to $250{ }^{\circ} \mathrm{C}$. The plastic deformation capacity increased with increasing temperature. However, at temperatures higher than $150^{\circ} \mathrm{C}$, the material exhibited dynamic recovery and $\eta^{\prime}$ 
phase coarsening, resulting in a decrease in tensile and yield stress. Tomoyoshi et al. [8] studied the influence of temperature on the stamping of 2024 aluminum alloy. When the temperature was $400{ }^{\circ} \mathrm{C}$, springback in the stamping part was reduced to zero. However, when the temperature rose to $500^{\circ} \mathrm{C}$, the sheet fractured as the temperature was close to the solidus temperature. Behrens et al. [9] studied the formability of 7022 and 7075 aluminum alloys at temperatures ranging from $150{ }^{\circ} \mathrm{C}$ to $300{ }^{\circ} \mathrm{C}$. At $300{ }^{\circ} \mathrm{C}$, the maximum strain increased. Xiao et al. [10] studied the formability of 7075 through hot uniaxial tensile tests. The forming limit was higher at $400{ }^{\circ} \mathrm{C}$ than at $20^{\circ} \mathrm{C}, 450{ }^{\circ} \mathrm{C}$, and $500{ }^{\circ} \mathrm{C}$. Sławomi et al. [11] studied the formability of 7075-T6 aluminum alloy vehicle supports between $20^{\circ} \mathrm{C}$ and $240{ }^{\circ} \mathrm{C}$. The parts broke at $20^{\circ} \mathrm{C}$. When the forming temperature was $240{ }^{\circ} \mathrm{C}$, parts were formed accurately, and the tensile stress of the material was reduced by $11 \%$ compared with the original state. Huo et al. [12] studied the formability and the microstructural evolution of 7075-T6 sheets at temperatures ranging from $20^{\circ} \mathrm{C}$ to $250^{\circ} \mathrm{C}$ through sheet bulging experiments. The results showed fine $\eta^{\prime}$ phase and GP zones at $200^{\circ} \mathrm{C}$, leading to the best formability.

Electromagnetic forming (EMF) is a high-speed forming technology that utilizes pulse magnetic field force to process metal [13-15]. In their classic review paper, Psyk et al. [16] pointed out that EMF can greatly reduce springback and improve the forming limit of materials compared with traditional quasi-static forming. Liu et al. [17] formed V-shaped parts with flanges through electromagnetic-assisted stamping (EMAS) using 5052 aluminum alloy. A uniform pressure coil was used to apply pulsed magnetic pressure to the whole part, which effectively reduced tensile stress on the outer surface and compressive stress on the inner surface. Cui et al. [18] proposed EMAS with magnetic force reverse loading. When the die structure did not change, springback in the V-shaped 5052 aluminum alloy part after stamping was reduced. The results show that the equivalent plastic strain and plastic dissipated energy increase after EMF, whereas the stress and elastic strain energy decrease. Cui et al. [19] proposed electromagnetic increment forming (EMIF), which was used to form large 3003 aluminum alloy parts with a moving discharge of small coils. Cui et al. [20] proposed an electromagnetic partitioning forming technology that can precisely manufacture and achieve springback control of large bending radius parts using 3003 aluminum alloy. During the process, elastic deformation is transformed into plastic deformation, and the residual stress is very small after EMF.

A great deal of research has been carried out on the formability of materials. Feng et al. [21] used a V-shaped die and tapered die to perform EMF of 5052 aluminum alloy plates. Compared with quasi-static stamping, maximum strain was increased by about $30 \%$ in the side wall of the V-shaped specimens and by about $100 \%$ in the tapering specimen. Fang et al. [22] performed drawing experiments using EMIF and 5052 aluminum alloy. Compared with quasi-static stamping, the drawing height was improved by $140 \%$ and the dislocation density was increased. Su et al. [23] compared the forming limits of 2219-O aluminum sheets under quasi-static, uniaxial electromagnetic force tensile, and dynamic tensile loads through unidirectional tensile experiments. Under the uniaxial electromagnetic force tensile condition, the forming limit of 2219-O sheets increased by $45.4 \%$ compared with the quasi-static tensile condition, and $3.7 \%$ to $4.3 \%$ compared with the dynamic tensile loading. Electromagnetic hot forming has also been proposed for difficult-to-deform materials. Xu et al. [24] studied the formability of AZ31 magnesium alloy sheets at different temperatures. When the temperature increased from $25{ }^{\circ} \mathrm{C}$ to $200{ }^{\circ} \mathrm{C}$, the forming limit increased. However, when the temperature rose to $250^{\circ} \mathrm{C}$, the forming limit decreased. In contrast to $25^{\circ} \mathrm{C}$ and $250{ }^{\circ} \mathrm{C}$, grain refinement was clearly observed at $200{ }^{\circ} \mathrm{C}$. Therefore, electromagnetic hot forming is an effective way to improve the formability of difficult-to-deform materials. However, previous research has mainly focused on aluminum alloy materials with good room-temperature plasticity. There are fewer studies on electromagnetic hot forming of high-strength aluminum alloys such as 7075 aluminum alloy. 
In this paper, electromagnetic hot forming of 7075-T6 aluminum alloy is proposed. The deformation behavior and mechanical properties of sheet metal were studied at different temperatures both macroscopically and microscopically via experimentation, and the forming process was analyzed using numerical simulations.

\section{Experiment}

\subsection{Experimental Apparatus}

Figure 1a shows the $200 \mathrm{~kJ}$ Electromagnetic Forming (EMF) machine (Central South University, Changsha, Hunan, China)and 100-ton hydraulic press (Zhongyou, Tengzhou, Shandong, China) used in the experiment. The rated voltage and capacitance of the EMF machine were $25 \mathrm{kV}$ and $640 \mu \mathrm{F}$, respectively. A Rogowski coil and oscilloscope were used to measure the discharge current flowing through the coil. Figure $1 \mathrm{~b}$ shows the experimental tool used for electromagnetic hot forming, including the coil, sheet, and forming die. During the hot forming process, the sheet is first heated in a heating stove, and then the mold-contained heating rods are used to press the sheet. Figure 1c shows the material resistance tester (Anbai, Changzhou, Jiangsu, China). In this study, the forming temperatures were set to $25^{\circ} \mathrm{C}, 200{ }^{\circ} \mathrm{C}, 300{ }^{\circ} \mathrm{C}$, and $400{ }^{\circ} \mathrm{C}$. The resistivity of aluminum alloy at different temperatures was obtained using a resistance tester.

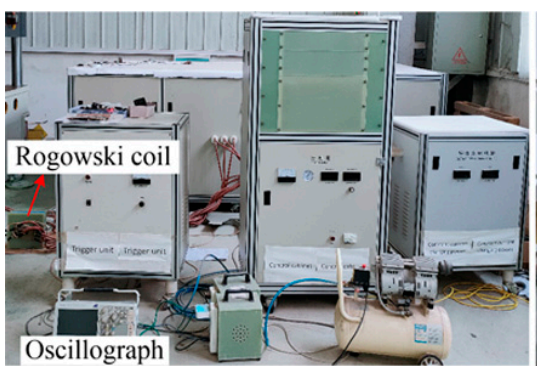

(a)

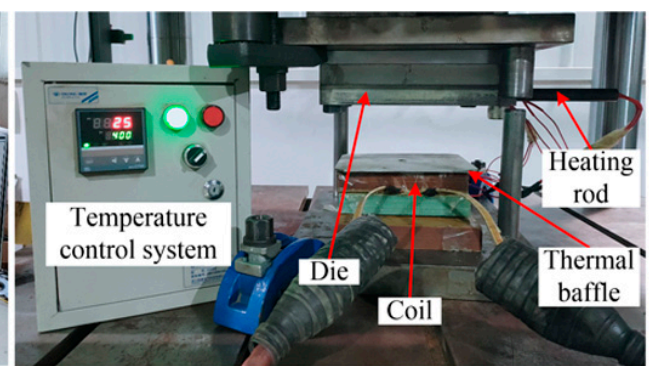

(b)

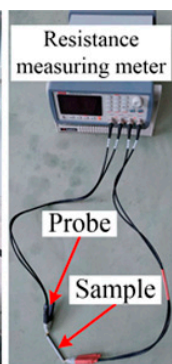

(c)

Figure 1. Experimental apparatus: (a) electromagnetic forming machine; (b) forming apparatus; (c) resistance measuring instruments.

Figure 2a shows the 2D structure of electromagnetic hot forming. The coil is a spiral structure. The cross section (length $\times$ width) of the coil wire was $3 \mathrm{~mm} \times 10 \mathrm{~mm}$, and the distance between each turn of the coil was $3 \mathrm{~mm}$. Figure 2a shows a three-dimensional (3D) drawing of the forming die. The diameter of the center opening of the forming die was $100 \mathrm{~mm}$, and the radius of the fillet was $10 \mathrm{~mm}$. Four holes were arranged on the side of the forming die to install the heating rod. The material used in the experiment was 7075-T6 aluminum alloy with the following dimensions: $200 \mathrm{~mm} \times 200 \mathrm{~mm} \times 1 \mathrm{~mm}$. To facilitate subsequent analysis, Path 1 on the sheet was selected. Two special nodes on Path 1 were selected. Node A is located at the sheet center, which is $100 \mathrm{~mm}$ away from the sheet edge. Node B is $70 \mathrm{~mm}$ away from the sheet edge, as shown in Figure 2c. 


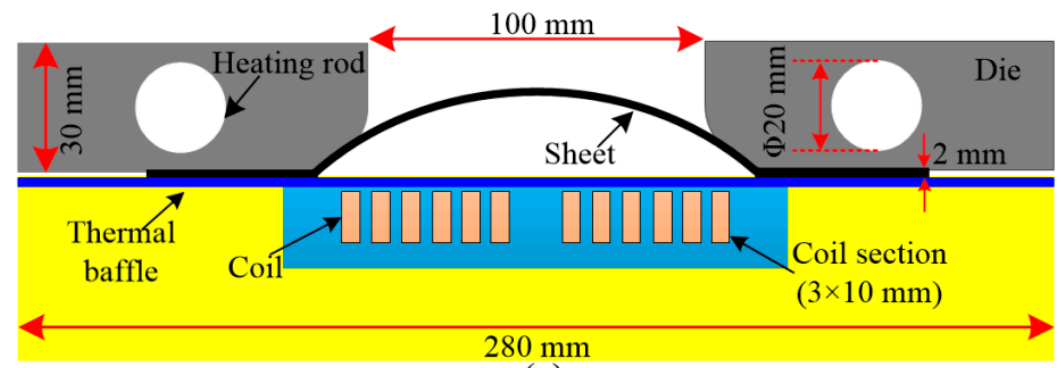

(a)

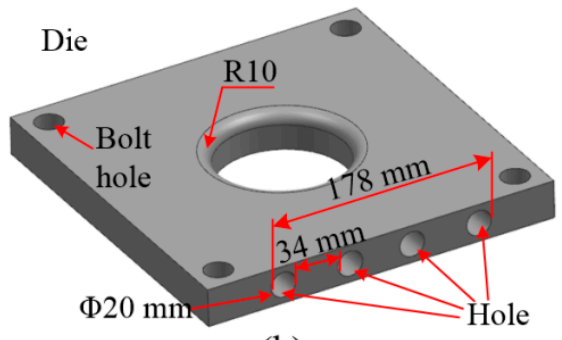

(b)

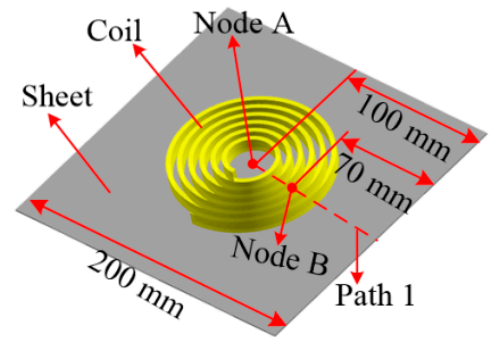

(c)

Figure 2. Structure of electromagnetic hot forming: (a) forming diagram; (b) forming die; (c) coil and sheet.

Figure 3 shows the current curves passing through the coil at different temperatures, when the discharge voltage is $5 \mathrm{kV}$. When the sheet temperature increases, the sheet resistance increases. The mutual inductance between the coil and the sheet decreases, while the total inductance of the discharge system increases with the sheet temperature increase. Thus, the peak current values decrease slightly at $400{ }^{\circ} \mathrm{C}$ compared with $200{ }^{\circ} \mathrm{C}$.

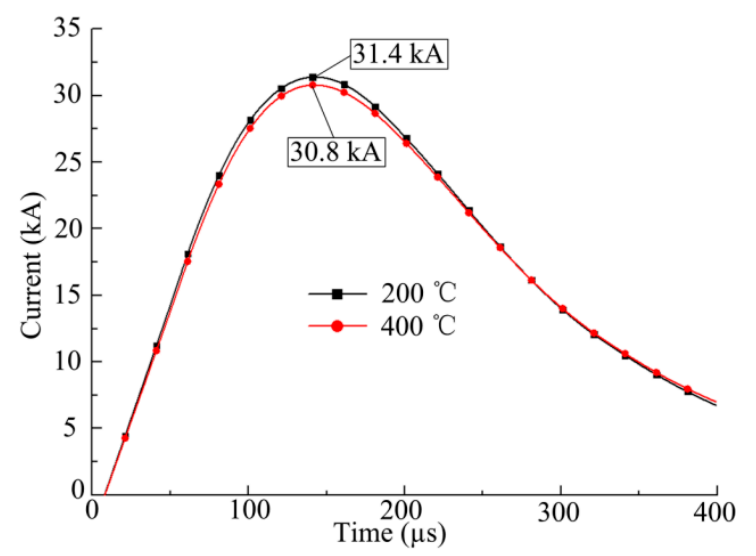

Figure 3. Current curve at $5 \mathrm{KV}$.

\subsection{Analysis of Forming Results}

Figure 4 shows the relationship between maximum forming height of sheet metal and voltage at different temperatures. The forming height increases with increasing voltage. The same trend was observed at each temperature. The forming height of sheet metal first decreased, then increased with increasing temperature. The forming height was lowest at $200{ }^{\circ} \mathrm{C}$ and highest at $400{ }^{\circ} \mathrm{C}$. 


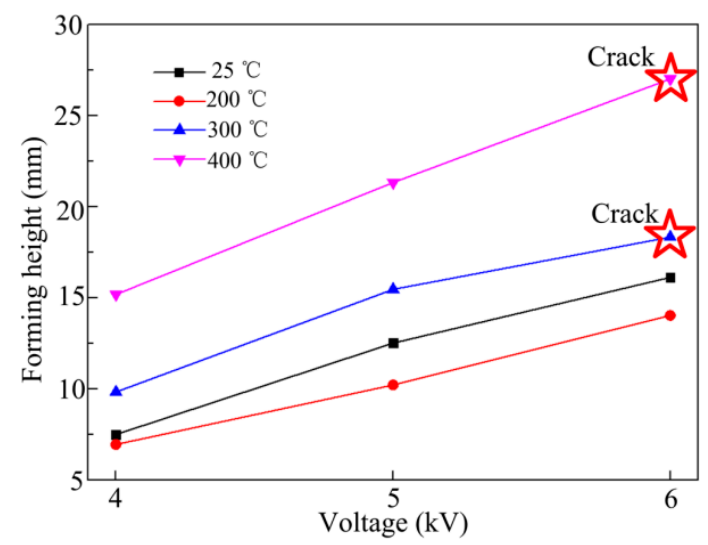

Figure 4. Change in sheet metal deformation with voltage at different forming temperatures.

Figure 5 shows the fracture types of the sheet metal for different voltages and temperatures. When the forming temperature was $25^{\circ} \mathrm{C}$ and the discharge voltage was $8 \mathrm{kV}$, necking occurred at the top of the sheet metal. When the forming temperature was $300{ }^{\circ} \mathrm{C}$ and $400{ }^{\circ} \mathrm{C}$, the edge of the sheet metal cracked under a discharge voltage of $6 \mathrm{kV}$.

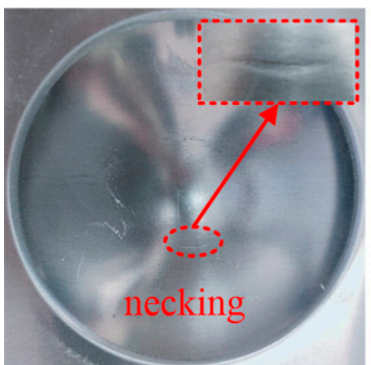

(a)

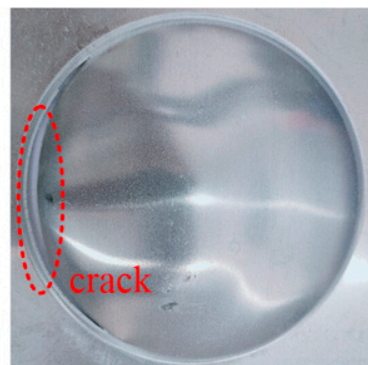

(b)

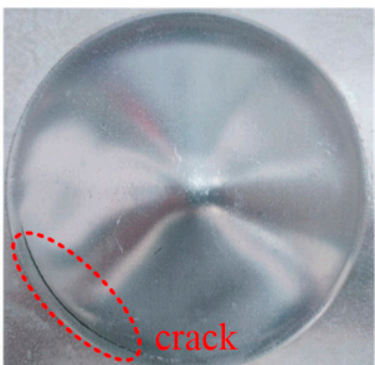

(c)

Figure 5. Fracture types at different voltages and temperatures: (a) $25^{\circ} \mathrm{C}, 8 \mathrm{kV}$; (b) $300{ }^{\circ} \mathrm{C}, 6 \mathrm{kV}$; (c) $400{ }^{\circ} \mathrm{C}, 6 \mathrm{kV}$.

The forming results of sheet metal at different temperatures with a discharge voltage of $5 \mathrm{kV}$ are shown in Figure 6. The forming heights at $25^{\circ} \mathrm{C}, 200{ }^{\circ} \mathrm{C}, 300{ }^{\circ} \mathrm{C}$ and $400{ }^{\circ} \mathrm{C}$ were $12.5 \mathrm{~mm}, 10.2 \mathrm{~mm}, 15.4 \mathrm{~mm}$ and $21.3 \mathrm{~mm}$, respectively. As the temperature increased, the forming height of the sheet metal first decreased, then increased. Compared with $25^{\circ} \mathrm{C}$, the forming height of sheet metal decreased by $18.5 \%$ at $200{ }^{\circ} \mathrm{C}$, while the forming heights at $300{ }^{\circ} \mathrm{C}$ and $400{ }^{\circ} \mathrm{C}$ increased by $23 \%$ and $70.4 \%$, respectively.

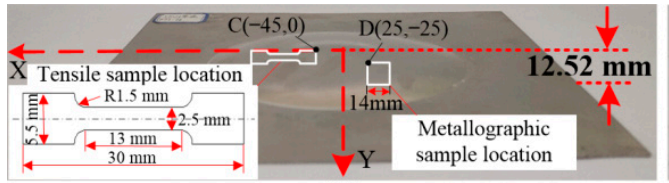

(a)

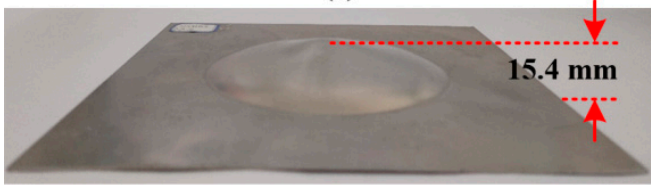

(c)

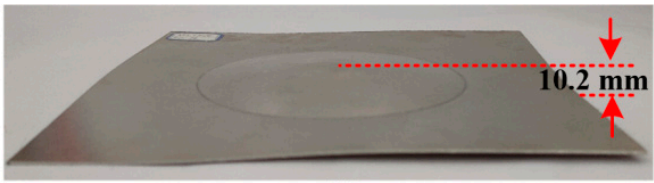

(b)

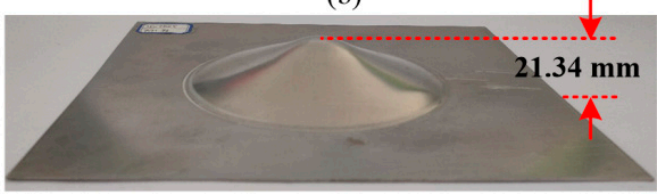

(d)

Figure 6. Experimental results for different forming temperatures at a voltage of $5 \mathrm{kV}$ : (a) $25{ }^{\circ} \mathrm{C}$; (b) $200{ }^{\circ} \mathrm{C}$; (c) $300{ }^{\circ} \mathrm{C}$; (d) $400{ }^{\circ} \mathrm{C}$.

After forming at $5 \mathrm{kV}$, mechanical properties of 7075-T6 sheets at different temperatures were examined. The tensile sample was cut with point $C(45,0)$ as the reference 
point, and the hardness sample was cut with point $\mathrm{D}(-25,-25)$ as the reference point, as shown in Figure 6a. Figure 7 shows the tensile curves and deformed samples obtained with different forming temperatures. At $25^{\circ} \mathrm{C}$, the yield stress, tensile stress, and hardness of the deformed material were $503 \mathrm{MPa}, 560 \mathrm{MPa}$, and $194 \mathrm{HV}$, respectively. At $200{ }^{\circ} \mathrm{C}$, the values were $475 \mathrm{MPa}, 521 \mathrm{MPa}$, and $184 \mathrm{HV}$, respectively. At $200{ }^{\circ} \mathrm{C}$, the yield stress, tensile stress, and hardness of the material decreased by $5.5 \%, 7 \%$, and $5.2 \%$, respectively, compared with $25^{\circ} \mathrm{C}$. At $300{ }^{\circ} \mathrm{C}$, the yield stress, tensile stress, and hardness of the deformed material were $231 \mathrm{MPa}, 379 \mathrm{MPa}$, and $108.3 \mathrm{HV}$, respectively. At $400{ }^{\circ} \mathrm{C}$, the values were $256 \mathrm{MPa}$, $450 \mathrm{MPa}$, and $142.7 \mathrm{HV}$, respectively. The mechanical properties of the material were lowest when the forming temperature was $300^{\circ} \mathrm{C}$. In addition, the forming height was lower at $200{ }^{\circ} \mathrm{C}$ compared with $25^{\circ} \mathrm{C}$. Therefore, the maximum forming height of the sheet metal and good mechanical properties were obtained with a forming temperature of $400{ }^{\circ} \mathrm{C}$.

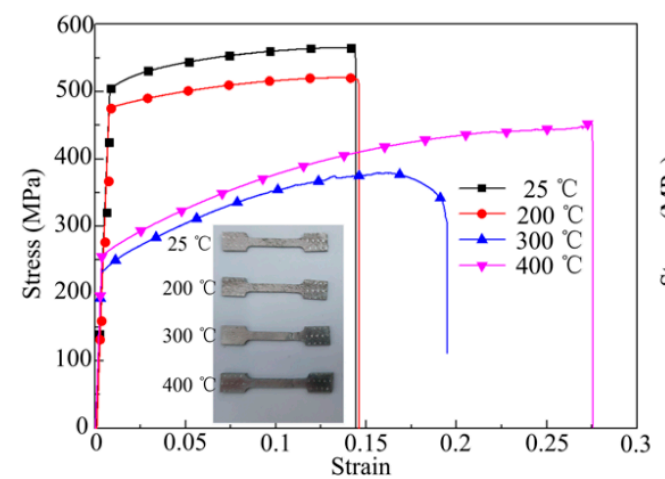

(a)

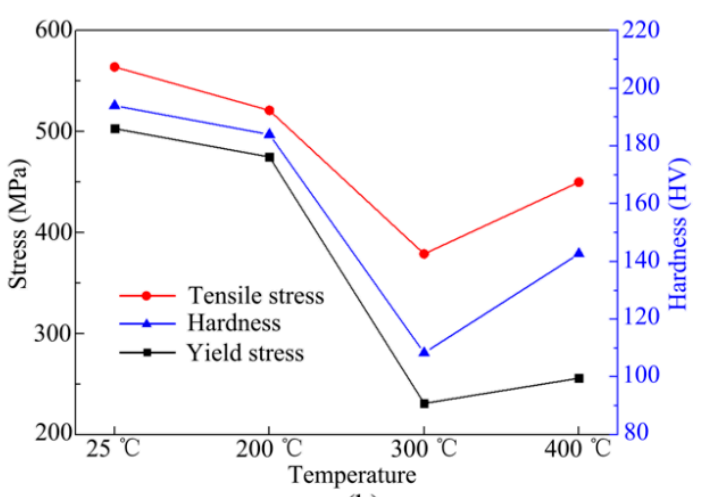

(b)

Figure 7. Mechanical properties of sheet metal after forming: (a) tensile curve; (b) stress and hardness curves.

\section{Finite Element Simulation}

A finite element model for electromagnetic field analysis was established in an ANSYS/EMAG (14.0) module, as shown in Figure 8a. The model includes the coil, sheet material, air field, and far field air. Figure $8 \mathrm{~b}$ shows the electromagnetic force distribution on the sheet at $400{ }^{\circ} \mathrm{C}$. Figure $8 \mathrm{c}$ shows the magnetic force distribution along Path 1. The magnetic force generated at node $\mathrm{A}$ is close to 0 , while the largest magnetic force occurs at node B. A finite element model of the deformation field was established in ABAQUS/EXCRITE (6.13), as shown in Figure 8d. The model consists of a die, a blank holder, and a sheet. To shorten the computation time, the die and blank holder were set as rigid bodies. In the simulation process, the electromagnetic force calculated in ANSYS (14.0) was imported into ABAQUS (6.13) to analyze the deformation of the sheet material. Then, the deformation results were imported into ANSYS/EMAG (14.0) to calculate the electromagnetic force for the next step.

The forming results at different temperatures $\left(200^{\circ} \mathrm{C}\right.$ and $\left.400{ }^{\circ} \mathrm{C}\right)$ were numerically simulated. The resistivity of the materials at $200{ }^{\circ} \mathrm{C}$ and $400{ }^{\circ} \mathrm{C}$ is $9.2 \times 10^{-8} \Omega \cdot \mathrm{m}$ and $12.9 \times 10^{-8} \Omega \cdot \mathrm{m}$, respectively. Figure 9 shows the stress-strain curves of 7075-T6 aluminum alloy at different temperatures. To investigate the influence of strain rate on the mechanical properties of the materials, the Johnson-Cook constitutive model was adopted, expressed as

$$
\sigma=\sigma_{\mathrm{s}}\left\lfloor 1+C \ln \varepsilon^{*}\right\rfloor
$$

where $\sigma_{\mathrm{s}}$ is the stress curve of different temperatures under quasi-static conditions (see Figure 9), and $C$ is the strain rate coefficient. For 7075-T6 aluminum alloy, $C=0.034$. $\varepsilon^{*}$ is the strain rate of the material. 


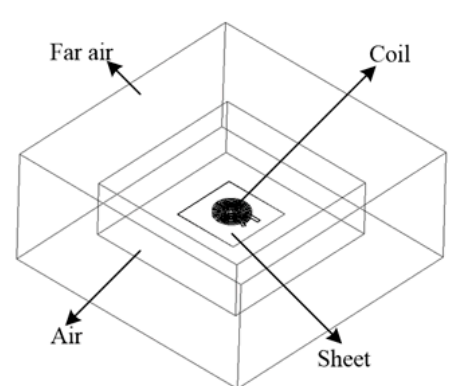

(a)

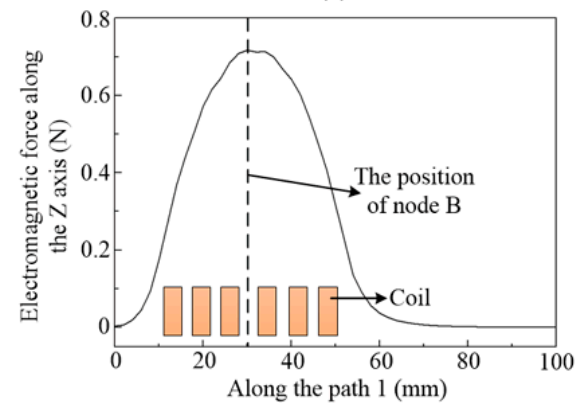

(c)

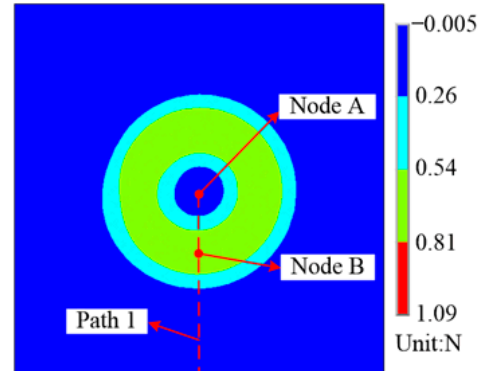

(b)

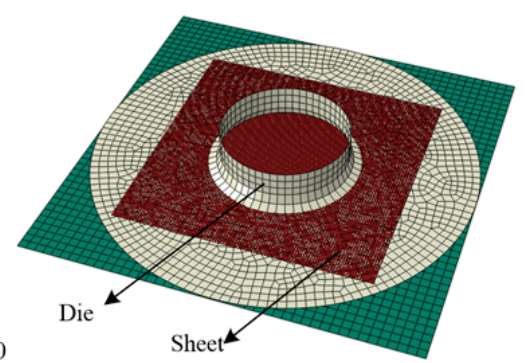

(d)

Figure 8. Finite element model of electromagnetic forming: (a) electromagnetic field model; (b) contours of magnetic force distribution; (c) magnetic force along Path 1; (d) structure field.

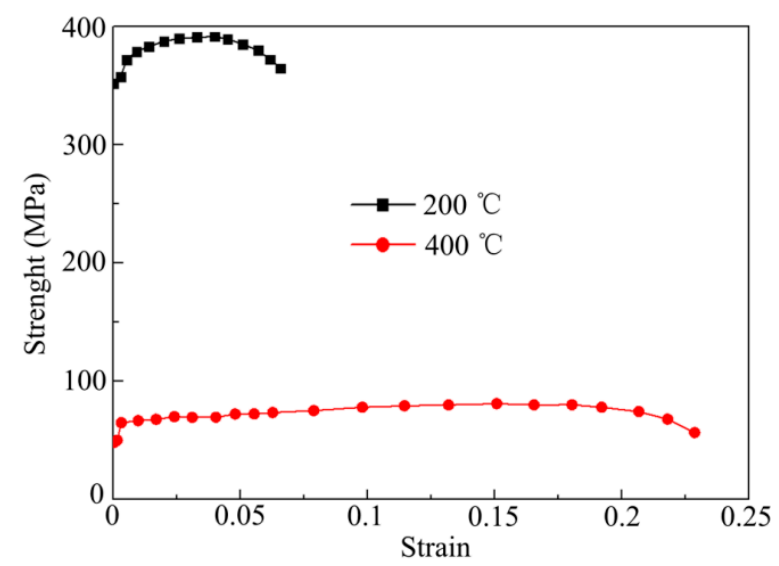

Figure 9. Stress-strain of materials at different temperatures.

Figure 10 shows the sheet deformation profiles obtained by experimentation and numerical simulation. At $200{ }^{\circ} \mathrm{C}$ and $400{ }^{\circ} \mathrm{C}$, the experimental forming heights are $10.2 \mathrm{~mm}$ and $21.34 \mathrm{~mm}$, respectively. The forming heights by simulation are $10.7 \mathrm{~mm}$ and $22.14 \mathrm{~mm}$, respectively. The maximum errors between the simulation and experiment are less than $6 \%$ at four temperatures. The simulation results are consistent with the experimental results. Moreover, the deformation profile at $200{ }^{\circ} \mathrm{C}$ is wavy, whereas the deformation profile at $400{ }^{\circ} \mathrm{C}$ is smooth.

From Figures 4-7 and 10, the forming height of the sheet at $200{ }^{\circ} \mathrm{C}$ is the lowest, and the sheet deformation uniformity is poor. At $400{ }^{\circ} \mathrm{C}$, the deformation uniformity and forming height of the parts are the best. Therefore, the deformation process was compared between $200^{\circ} \mathrm{C}$ and $400{ }^{\circ} \mathrm{C}$. Figure 11 a shows the sheet deformation profile at different time points during the forming process at $200{ }^{\circ} \mathrm{C}$. The sheet forming height is highest at $180 \mu \mathrm{s}$, and then vibration appears in the sheet, resulting in a wavy profile. Figure $11 \mathrm{~b}$ shows the deformed profile at different time points during the forming process at $400{ }^{\circ} \mathrm{C}$. Yield stress in the material is greatly reduced, leading to a significant reduction in the vibration of the 
material during deformation, compared with $200{ }^{\circ} \mathrm{C}$. At the forming temperature of $400{ }^{\circ} \mathrm{C}$, when the deformation is terminated, the deformation profile is uniform.

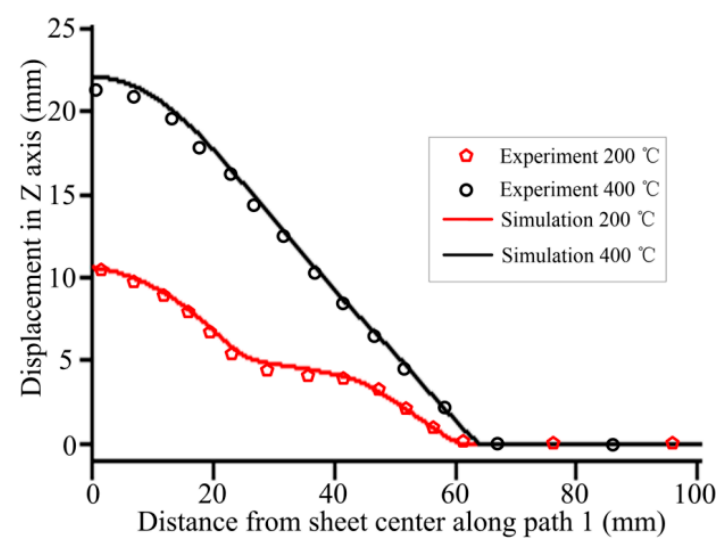

Figure 10. Comparison of simulated and experimental deformed profiles.

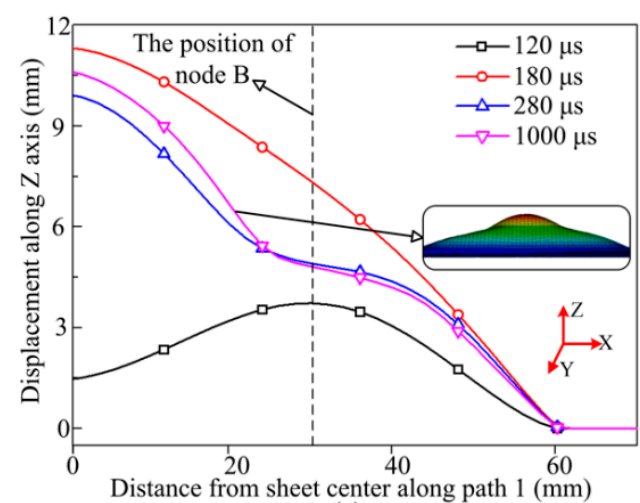

(a)

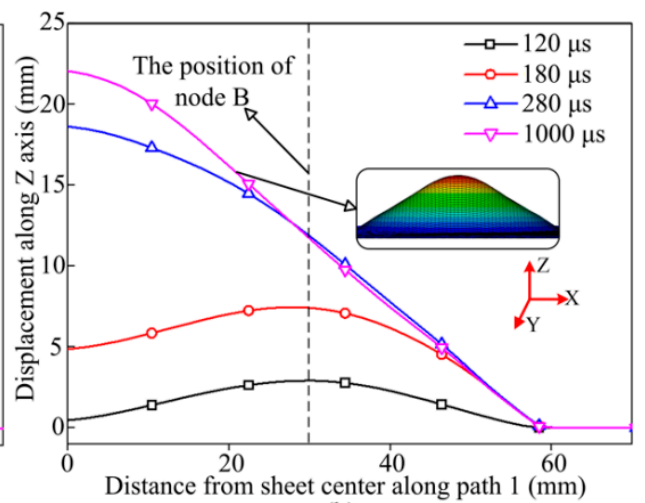

(b)

Figure 11. Deformation profile of sheet material at different time points during the forming process at different temperatures: (a) $200{ }^{\circ} \mathrm{C}$; (b) $400{ }^{\circ} \mathrm{C}$.

Figure $12 \mathrm{a}$ shows the equivalent plastic strain on the sheet at $200{ }^{\circ} \mathrm{C}$ at different times. After $180 \mu$ s, the equivalent plastic strain on the sheet increases. The equivalent plastic strain appears wavy at $1000 \mu \mathrm{s}$. Figure $12 \mathrm{~b}$ shows the equivalent plastic strain on the sheet at $400{ }^{\circ} \mathrm{C}$ at different times. After $180 \mu \mathrm{s}$, the equivalent plastic strain increases sharply over time. The strain on the sheet is uniformly distributed. At $1000 \mu \mathrm{s}$, the greater the distance away from the sheet center, the smaller the plastic strain appears.

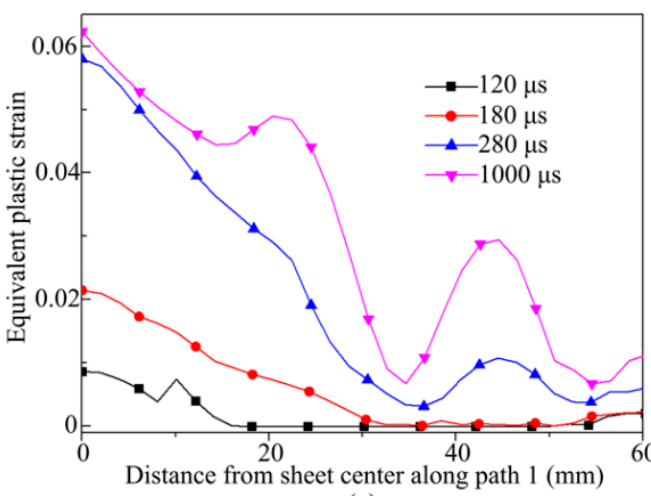

(a)

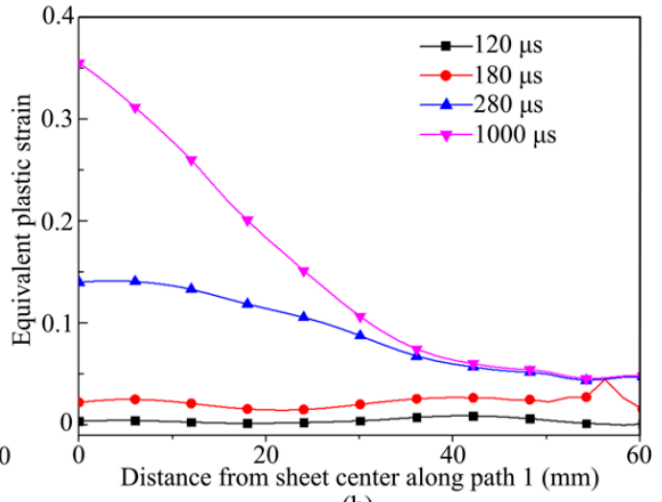

(b)

Figure 12. Equivalent plastic strain of sheet material at different time points during the forming process at different temperatures: (a) $200{ }^{\circ} \mathrm{C}$; (b) $400{ }^{\circ} \mathrm{C}$. 
Figure 13 shows three principal stresses with time of node A at a voltage of $5 \mathrm{kV}$ and forming temperatures of $200{ }^{\circ} \mathrm{C}$ and $400{ }^{\circ} \mathrm{C}$. $\sigma_{1}$ is along the tangential direction of the sheet, $\sigma_{2}$ is along the width direction of the sheet, and $\sigma_{3}$ is along the thickness direction of the sheet. At $200{ }^{\circ} \mathrm{C}, \sigma_{1}$ reaches its first peak of $571 \mathrm{MPa}$ at $120 \mu \mathrm{s}$, and $\sigma_{2}$ and $\sigma_{3}$ reach $515 \mathrm{MPa}$ and $-35 \mathrm{MPa}$, respectively. At $400{ }^{\circ} \mathrm{C}, \sigma_{1}$ reaches its first peak value of $110 \mathrm{MPa}$ at $160 \mu \mathrm{s}$, and $\sigma_{2}$ and $\sigma_{3}$ are $91 \mathrm{MPa}$ and $-1 \mathrm{MPa}$, respectively. The stress state of node $\mathrm{A}$ is approximately bidirectional isotension. After $\sigma_{1}$ reaches its first peak, the stress oscillates significantly.

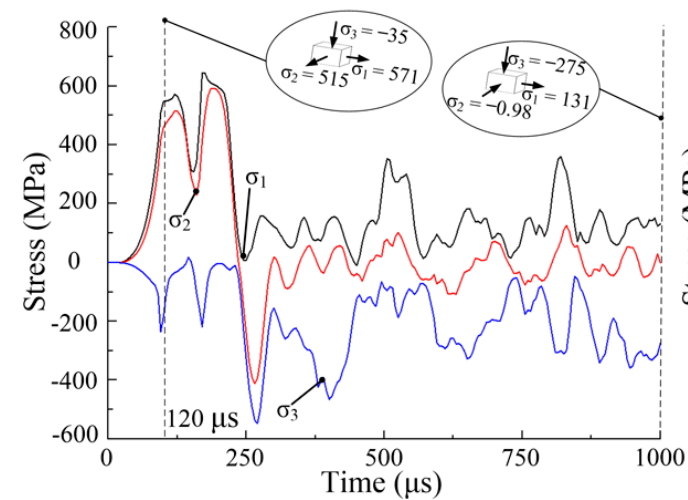

(a)

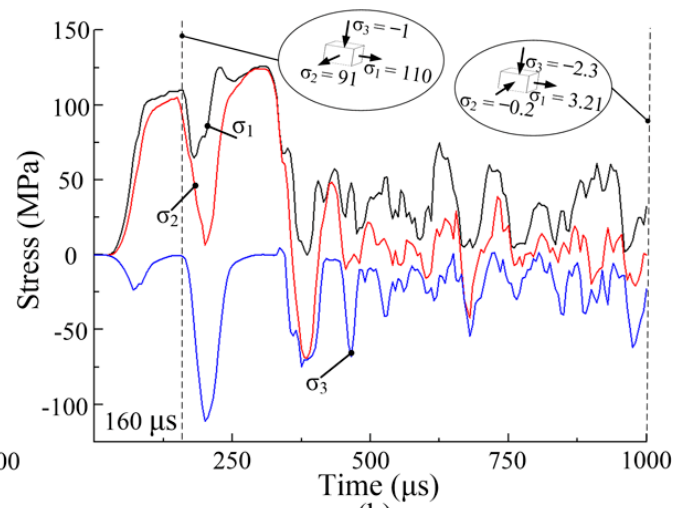

(b)

Figure 13. Variation of three principal stresses with time at node A during the forming process at different temperatures: (a) $200{ }^{\circ} \mathrm{C}$; (b) $400{ }^{\circ} \mathrm{C}$.

Figure 14 shows three principal stresses and time curve of node $\mathrm{B}$ at a voltage of $5 \mathrm{kV}$ and forming temperatures of $200^{\circ} \mathrm{C}$ and $400{ }^{\circ} \mathrm{C}$. At $200{ }^{\circ} \mathrm{C}, \sigma_{1}$ reaches its first peak value of $587 \mathrm{MPa}$ at $185 \mu \mathrm{s}$, and $\sigma_{2}$ and $\sigma_{3}$ are $386 \mathrm{MPa}$ and $-30 \mathrm{MPa}$, respectively. At $400{ }^{\circ} \mathrm{C}, \sigma_{1}$ reaches its first peak value of $104 \mathrm{MPa}$ at $155 \mu \mathrm{s}$, and $\sigma_{2}$ and $\sigma_{3}$ are 87.3 MPa and $-19.4 \mathrm{MPa}$, respectively. Node B is subjected to bidirectional tensile stress. Similar to node A, the stress oscillates and gradually decreases after the first peak. From Figures 13 and 14, the three principal stresses first increase and then oscillate and decay. Moreover, smaller stresses appear on the sheet after the sheet deformation at $400{ }^{\circ} \mathrm{C}$, compared with $200^{\circ} \mathrm{C}$. Therefore, the sheet forming at a higher temperature can obviously reduce the internal stress of sheet metal. Many scholars have found that stress oscillation leads to a large decrease in the internal stress of the sheet during the EMF process, which can reduce the springback of the sheet [25-27].

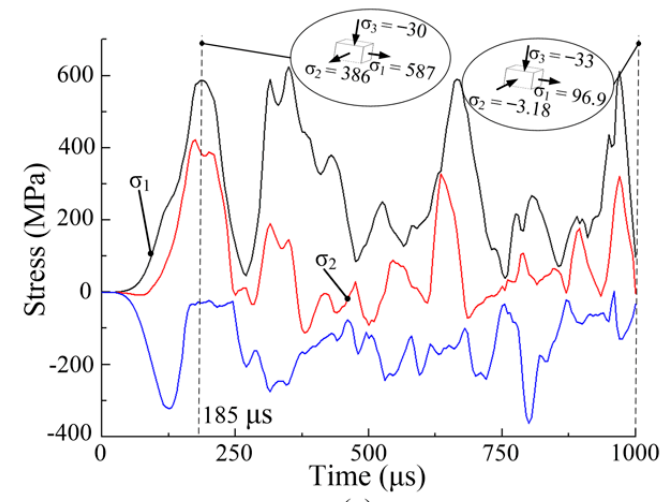

(a)

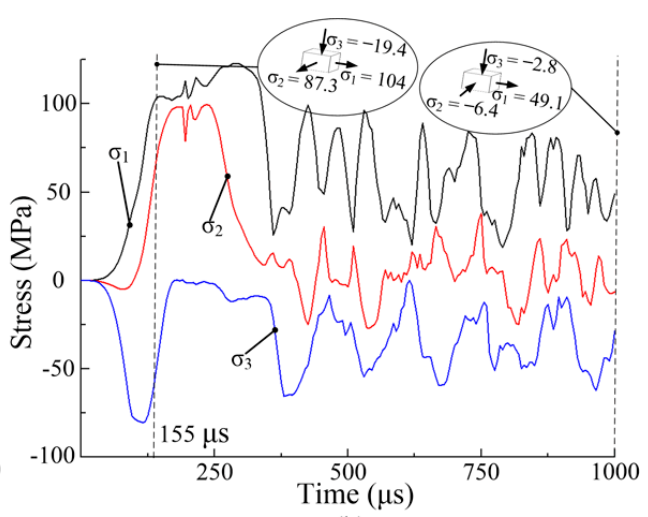

(b)

Figure 14. Variation of three principal stresses with time at node B: (a) $200{ }^{\circ} \mathrm{C}$; (b) $400{ }^{\circ} \mathrm{C}$.

Figure $15 \mathrm{a}, \mathrm{b}$ show the equivalent plastic strain and plastic strain rate of node $\mathrm{A}$ when the discharge voltage is $5 \mathrm{kV}$. At $200^{\circ} \mathrm{C}$, the maximum equivalent plastic strain and 
plastic strain rate of node A are 0.058 and $1692 \mathrm{~s}^{-1}$, respectively. At $400{ }^{\circ} \mathrm{C}$, the maximum equivalent plastic strain and plastic strain rate of node $A$ are 0.322 and $3981 \mathrm{~s}^{-1}$, respectively. The equivalent plastic strain increases at first and then remains stable. Compared with a forming temperature of $200{ }^{\circ} \mathrm{C}$, a larger plastic strain and strain rate in the sheet metal were obtained at $400^{\circ} \mathrm{C}$. This is because yield stress decreases with increasing temperature, leading to greater plastic deformation of the sheet metal at $400^{\circ} \mathrm{C}$.

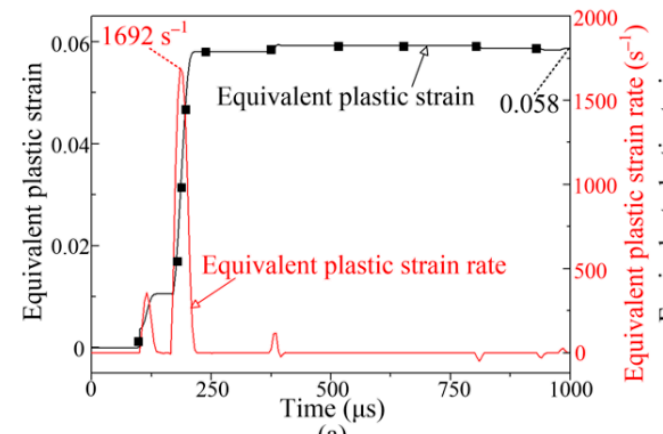

(a)

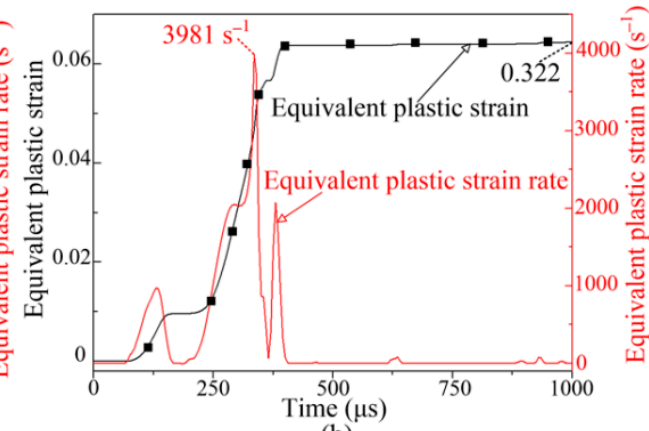

(b)

Figure 15. Equivalent plastic strain and strain rate: (a) $200{ }^{\circ} \mathrm{C}$, node $\mathrm{A}$; (b) $400{ }^{\circ} \mathrm{C}$, node $\mathrm{A}$.

\section{Discussion of Results}

The microstructure of the deformed sheet was observed and analyzed through a transmission electron microscope (TEM). The TEM samples were prepared by the electrolytic double-spray method. The electrolytic double-spray solution was a mixture of $30 \%$ nitric acid and $70 \%$ methanol. The temperature was controlled by liquid nitrogen at $-35^{\circ} \mathrm{C}--25^{\circ} \mathrm{C}$. Figure 16 shows the changes in size of the second phase of the material at $200{ }^{\circ} \mathrm{C}, 300{ }^{\circ} \mathrm{C}$, and $400{ }^{\circ} \mathrm{C}$. In the forming process of the 7075-T6 aluminum alloy, the main second phase is the $\eta$ phase. With the increase of temperature, the $\eta$ phase will be coarser. The increase of $\eta$ phase size will weaken the strengthening effect and decrease the mechanical properties, as shown in Equation (2) [28]:

$$
\sigma=C \bullet f_{t}^{1 / 2} \bullet r^{-1}
$$

where $\sigma$ represents precipitate hardening, $C$ is material constants, $f_{t}$ is the volume fraction of precipitates, and $r$ is the particle size.

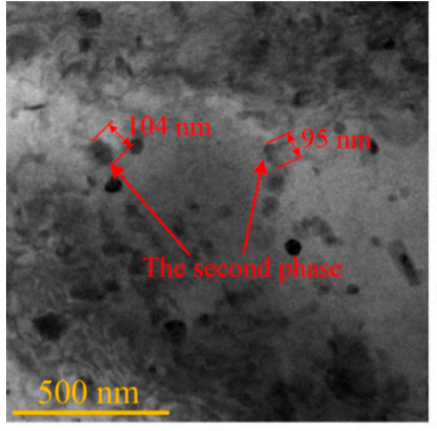

(a)

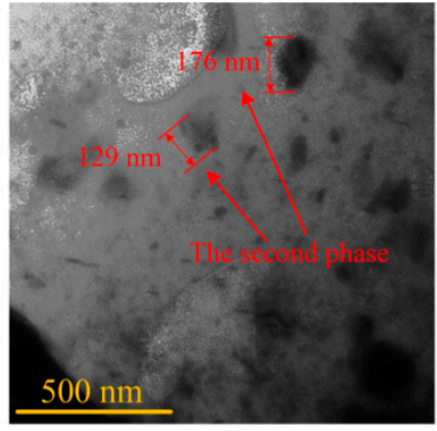

(b)

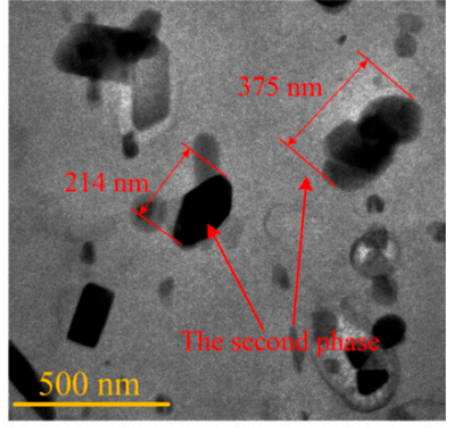

(c)

Figure 16. The distribution of the second phase particles: (a) $200{ }^{\circ} \mathrm{C}$; (b) $300{ }^{\circ} \mathrm{C}$; (c) $400{ }^{\circ} \mathrm{C}$.

Compared with $25{ }^{\circ} \mathrm{C}, 200{ }^{\circ} \mathrm{C}$, and $300{ }^{\circ} \mathrm{C}$, the second phase was further coarsened at $400{ }^{\circ} \mathrm{C}$. Thus, the change of the second phase at $400^{\circ} \mathrm{C}$ was not the main factor affecting mechanical properties of the material. In order to analyze the reason for the improvement of mechanical properties at $400{ }^{\circ} \mathrm{C}$, the changes of grain size with temperature were analyzed. The metallographic experiments were performed with an optical digital microscope. Figure 17 shows the grain distributions after sheet forming. The average grain size was 
about $32 \mu \mathrm{m}, 33 \mu \mathrm{m}, 34 \mu \mathrm{m}$, and $16 \mu \mathrm{m}$ at $25^{\circ} \mathrm{C}, 200{ }^{\circ} \mathrm{C}, 300{ }^{\circ} \mathrm{C}$, and $400{ }^{\circ} \mathrm{C}$, respectively. The grain refinement occurs at $400{ }^{\circ} \mathrm{C}$ compared with other forming temperatures. This is because the dynamic recovery effect appears at $400{ }^{\circ} \mathrm{C}$ for 7075 aluminum alloy [29]. Based on the Hall-Petch relationship (Equation (3)) [30], the mechanical properties of the material improve if the grain size decreases. Therefore, the material stress and hardness increase as the forming temperature increases from $300{ }^{\circ} \mathrm{C}$ to $400{ }^{\circ} \mathrm{C}$.

$$
\sigma=\sigma_{0}+k \bullet d^{-1 / 2}
$$

where $\sigma$ and $\sigma_{0}$ represent the yield stress and the friction stress when dislocations glide on the slip plane, respectively, $k$ represents material constants, and $d$ is the grain size.

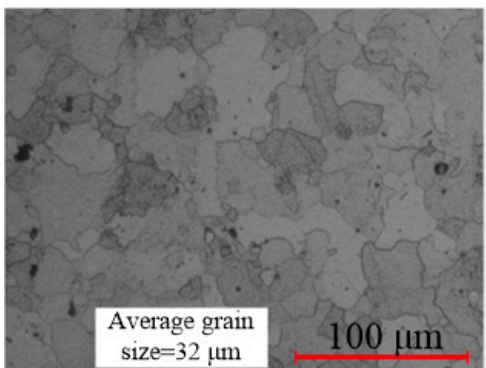

(a)

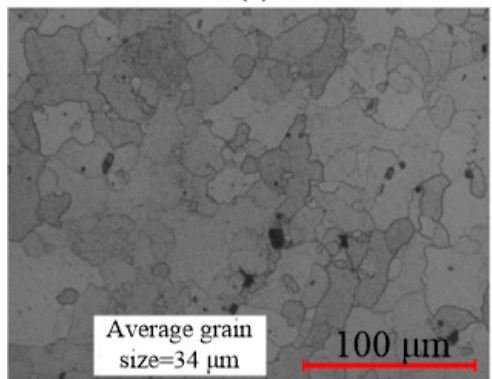

(c)

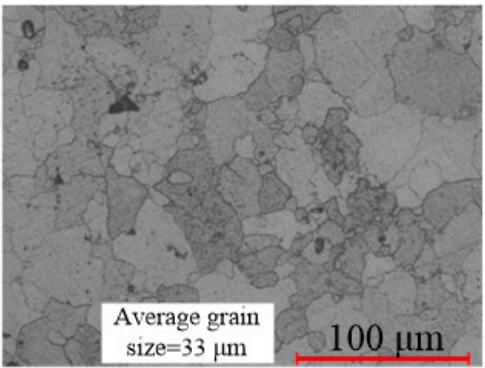

(b)

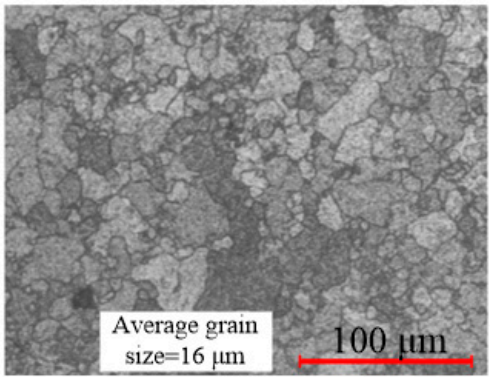

(d)

Figure 17. Grain distribution in sheet metal with different forming temperatures: (a) $25^{\circ} \mathrm{C}$; (b) $200{ }^{\circ} \mathrm{C}$; (c) $300{ }^{\circ} \mathrm{C}$; (d) $400{ }^{\circ} \mathrm{C}$.

\section{Conclusions}

7075 aluminum alloy is easy to break at room temperature. In order to increase the forming height of 7075 aluminum alloy, electromagnetic hot forming is proposed. The simulation and experimental results at $25^{\circ} \mathrm{C}, 200{ }^{\circ} \mathrm{C}, 300{ }^{\circ} \mathrm{C}$, and $400{ }^{\circ} \mathrm{C}$ were compared to prove the accuracy of the FEM model. The main conclusions can be summarized as follows:

(1) Compared with a forming temperature of $200^{\circ} \mathrm{C}$, a more uniform deformation profile and larger plastic strain and strain rate, as well as smaller stresses in the sheet metal, were obtained at $400{ }^{\circ} \mathrm{C}$.

(2) When the temperature was increased from $25^{\circ} \mathrm{C}$ to $400{ }^{\circ} \mathrm{C}$, the deformation height first decreased, then increased. The lowest deformation height occurred at $200{ }^{\circ} \mathrm{C}$.

(3) When the forming temperature was increased from $25^{\circ} \mathrm{C}$ to $400{ }^{\circ} \mathrm{C}$, the stress and hardness first decreased, then increased. The least favorable mechanical properties occurred at $300{ }^{\circ} \mathrm{C}$. This is because of obvious coarsening in the second phase at $300{ }^{\circ} \mathrm{C}$. Continuous dynamic recrystallization of 7075 aluminum alloy occurs at $400{ }^{\circ} \mathrm{C}$, which leads to grain refinement and improved mechanical properties.

Author Contributions: The research was conceived by X.C. and Z.D. (Zhihao Du); Z.D. (Zhihao Du). and Z.D. (Zanshi Deng) planned and performed all the experiments; A.X. collected all data; theoretical and experimental analysis were performed by Z.D. (Zhihao Du), X.C. and A.X.; the manuscript was reviewed by X.C. and Z.D. (Zhihao Du); the manuscript was written by Z.D. (Zhihao $\mathrm{Du})$. All authors have read and agreed to the published version of the manuscript. 
Funding: This work was supported by the National Natural Science Foundation of China (Grant Number: 51775563 and 51405173), Innovation Driven Program of Central South University (Grant number: 2019CX006), and the Project of State Key Laboratory of High Performance Complex Manufacturing, Central South University (ZZYJKT2020-02).

Institutional Review Board Statement: Not applicable.

Informed Consent Statement: Not applicable.

Data Availability Statement: Data is contained within the article.

Conflicts of Interest: The authors declare that they have no conflict of interest in this work. We declare that we do not have any commercial or associative interest that represents a conflict of interest in connection with the work.

\section{References}

1. Rasoul, J.N.; Ali, F.; Mahdi, S. Electromagnetically activated high-speed hydroforming process: A novel process to overcome the limitations of the electromagnetic forming process. CIRP J. Mater. Sci. Technol. 2019, 27, 21-30. [CrossRef]

2. Yu, H.P.; Sun, L.C.; Zhang, X.; Wang, S.L.; Li, C.F. Experiments on electrohydraulic forming and electromagnetic forming of aluminum tube. Int. J. Adv. Manuf. Technol. 2017, 89, 3169-3176.

3. Zhang, Z.Q.; Zhang, X.K.; He, D.Y. Forming and warm die quenching process for AA7075 aluminum alloy and its application. J. Mater. Eng. Perform. 2020, 29, 620-625.

4. Rong, H.; Hu, P.; Ying, L.; Hou, W.B.; Zhang, J.H. Thermal forming limit diagram (TFLD) of AA7075 aluminum alloy based on a modifified continuum damage model: Experimental and theoretical investigations. Int. J. Mech. Sci. 2019, 156, 59-73.

5. Xiao, D.; Peng, X.Y.; Liang, X.P.; Deng, Y.; Xu, G.F.; Yin, M.Z. Research on Constitutive Models and Hot Workability of AsHomogenized Al-Zn-Mg-Cu Alloy During Isothermal Compression. Met. Mater. Int. 2017, 23, 591-602.

6. Wang, L.; Strangwood, M.; Balint, D.; Lin, J.; Dean, T.A. Formability and failure mechanisms of AA2024 under hot forming conditions. Mater. Sci. Eng. A 2011, 528, 2648-2656.

7. Kumar, M.; Sotirov, N.; Chimani, C.M. Investigations on warm forming of AW-7020-T6 alloy sheet. J. Mater. Proc. Technol. 2014, $214,1769-1776$.

8. Tomoyoshi, M.; Ken-ichiro, M.; Ryosuke, Y. Hot stamping of high-strength aluminium alloy aircraft parts using quick heating. CIRP Ann. Manuf. Technol. 2017, 66, 269-272.

9. Behrens, B.; Nürnberger, F.; Bonk, C. Inflfluences on the formability and mechanical properties of 7000-aluminum alloys in hot and warm forming. J. Phys. Conf. Ser. 2017, 896, 12004.

10. Xiao, W.C.; Wang, B.Y.; Zheng, K.L. An experimental and numerical investigation on the formability of AA7075 sheet in hot stamping condition. Int. J. Adv. Manuf. Technol. 2017, 92, 3299-3309.

11. Sławomir, P.; Paweł, K.; Zbigniew, G. Warm forming of 7075 aluminum alloys. Procedia Eng. 2017, $207,2399-2404$.

12. Huo, W.T.; Hou, L.G.; Zhang, Y.S. Warm formability and post-forming microstructure/property of high-strength AA 7075-T6 Al alloy. Mater. Sci. Eng. A 2016, 675, 44-54.

13. Hyeonil, P.; Daeyong, K.; Jinwoo, L.; Se-Jong, K.; Youngseon, L. Effect of an aluminum driver sheet on the electromagnetic forming of DP780 steel sheet. J. Mater. Proc. Technol. 2016, 235, 158-170.

14. Zhang, S.Y.; Ali, N.; Brad, K. Numerical Model and Experimental Investigation of Electromagnetic Tube Compression with Field Shaper. Procedia Manuf. 2018, 26, 537-542.

15. Xiong, W.R.; Wang, W.P.; Wan, M.; Li, X.J. Geometric issues in V-bending electromagnetic forming process of 2024-T3 aluminum alloy. J. Manuf. Process. 2015, 19, 171-182.

16. Psyk, V.; Risch, D.; Kinsey, B.L.; Tekkaya, A.E.; Kleiner, M. Electromagnetic forming-A review. J. Mater. Proc. Technol. 2011, 211, 787-829.

17. Liu, W.; Zou, X.F.; Huang, S.Y.; Lei, Y. Electromagnetic-assisted calibration for surface part of aluminum alloy with a dedicated uniform pressure coil. Int. J. Adv. Manuf. Technol. 2019, 100, 721-727.

18. Cui, X.H.; Zhang, Z.W.; Du, Z.H.; Yu, H.L. Inverse bending and springback-control using magnetic pulse forming. J. Mater. Proc. Technol. 2020, 275, 116374 .

19. Cui, X.H.; Mo, J.H.; Li, J.J. Electromagnetic incremental forming (EMIF): A novel aluminum alloy sheet and tube forming technology. J. Mater. Proc. Technol. 2014, 214, 409-427.

20. Cui, X.H.; Du, Z.H.; Xiao, A.; Yan, Z.Q. Electromagnetic partitioning forming and springback control in the fabrication of curved parts. J. Mater. Proc. Technol. 2021, 288, 116889.

21. Feng, F.; Li, J.J.; Huang, L.; Su, H.L.; Li, H.Z.; Zhang, Y.J.; Cao, S.J. Formability enhancement of 5052 aluminium alloy sheet in electromagnetic impaction forming. Int. J. Adv. Manuf. Technol. 2021, 112, 2639-2655.

22. Fang, J.X.; Mo, J.H.; Li, J.J. Microstructure difference of 5052 aluminum alloys under conventional drawing and electromagnetic pulse assisted incremental drawing. Mater. Charact. 2017, 129, 88-97.

23. Su, H.L.; Huang, L.; Li, J.J.; Zhu, H.; Feng, F.; Li, H.W.; Yan, S.L. Formability of AA 2219-O sheet under quasi-static, electromagnetic dynamic, and mechanical dynamic tensile loadings. J. Mater. Sci. Technol. 2021, 70, 125-135. 
24. Xu, J.R.; Xie, X.Y.; Wen, Z.S.; Cui, J.J.; Zhang, X.; Zhu, D.B.; Liu, L. Deformation behaviour of AZ31 magnesium alloy sheet hybrid actuating with $\mathrm{Al}$ driver sheet and temperature in magnetic pulse forming. J. Manuf. Process. 2019, 37, 402-412.

25. Golovashchenko, S.F. Springback calibration using pulsed electromagnetic field. AIP Conf. Proc. 2005, 778, $284-285$.

26. Iriondo, E.; Alcaraz, J.L.; Daehn, G.S.; Gutiérrez, M.A.; Jimbert, P. Shape calibration of high strength metal sheets by electromagnetic forming. J. Manuf. Process. 2013, 15, 183-193.

27. Wang, X.; Huang, L.; Li, J.J.; Su, H.L.; Feng, F.; Ma, F. Investigation of springback during electromagnetic-assisted bending of aluminium alloy sheet. Int. J. Adv. Manuf. Technol. 2019, 105, 375-394.

28. Zhang, Q.L.; Luan, X.; Du, J.Q.; Fu, M.W.; Wang, K.H. Development of the post-form strength prediction model for a high strength 6xxx aluminium alloy with pre-existing precipitates and residual dislocations. Int. J. Plast. 2019, 119, $230-248$.

29. Gourdet, S.; Montheillet, F. A model of continuous dynamic recrystallization. Acta Mater. 2003, 51, 2685-2699.

30. Yu, H.H.; Xin, Y.C.; Wang, M.Y.; Liu, Q. Hall-Petch relationship in Mg alloys: A review. J. Mater. Sci. Technol. 2018, 34, 248-256. 